\title{
GROWTH PERFORMANCE OF NILE TILAPIA (Oreochromis niloticus) FINGERLINGS FED DIET SUPPLEMENTED WITH DIFFERENT OF SPIRULINA PLATENSIS LEVELS
}

\author{
A. Abo El-Ward ${ }^{1}$, A.E. Eid, ${ }^{2}$, K.A. Mohamed ${ }^{3}$, B. Abd-elfattah ${ }^{4}$ and M.A. Hasan ${ }^{5}$ \\ 1- Agriculture Research Center, Port Saied Governorate, Egypt, 2.3,4 Faculty of Agriculture, Suez Canal \\ University, Ismailia, Egypt, 5- Lab. of Nutrition, Central laboratory of fish Research. Abbassa- Abohamad- \\ Sharkia
}

\section{SUMMARY}

The present study was designed to evaluate the use of spirulina (Spirulina platensis) as a replacement of different protein levels for Nile tilapia (Oreochromis niloticus) fingerlings. Spirulina was incorporated into four isonitrogenous and isocaloric diets at 0, 5, 10, 15 and 20\% of the protein-based diet. The diets were fed to the fishat satiation twice a day for 56 days. The final weight gain, specific growth rate, protein efficiency ratio and survival rate of fish were significantly $(p<0.05)$ higher for group of fish fed diet supplemented with 20\% Spirulina platensis from diet protein. The lowest feed conversion ratio was obtained for group of fish fed $20 \%$ Spirulina. There was a significant difference $(p<0.05)$ in protein and lipid in carcass proximate composition of the fish fed on diet replacement with $20 \%$ spirulina from diet protein compared to those on the experimental groups.

Moreover, fish fed diets containing different spirulina levels exhibited higher protein, serum creatinine, urea, albumin, globulin, triglycerides $H D L-C$ values. On contrary, significant $(P<0.05)$ decreased was observed for Albumin /Globulin Ratio, LDL-CAST, ALT and AST values compared with the control. Serum protein (g/dl), creatinine $(\mathrm{mg} / \mathrm{dl})$, urea $(\mathrm{mg} / \mathrm{dl})$ albumin $(\mathrm{g} / \mathrm{dl})$, globulin $(\mathrm{g} / \mathrm{dl})$ and triglycerides $(\mathrm{mg} / \mathrm{dl})$ values weresignificantly increased $(P<0.05)$ with the increase of Spirulina levels being the highest at T4 $(20 \%$ Spirulina/kg) diet. This study demonstrates that up to $20 \%$ of spirulina replacement was most effective in stimulating fish growth for Nile tilapia (Oreochromis niloticus) fingerlings.

Keywords: Spirulina platensis, replacement, Nile tilapia, growth performance, feed utilization, carcass composition

\section{INTRODUCTION}

Tilapia (Oreochromis niloticus) is widely cultured in the world. They tolerate a wide range of water quality conditions and could develop resistant to many diseases. Tilapia is a hardy prolific, fast growing tropical fish, and it can survive on a diversity of food (El-Sayed, 2006). One of the biggest problems facing the utilization of fish nutrition, in many aquaculture operations today, feed accounts more than half of the variable operating cost (NRC, 2011). Therefore, the potential use of unconventional foodstuffs such as algae, for substitution the high cost ingredients such as fishmeal is very important. Algae have attention as a possible alternative protein source for cultured fish, particular in tropical and subtropical developing countries where algae production rates are high and their higher protein, vitamins and essential fatty acids contents (El-Hindawy et al., 2006 and Badawy et al., 2008). Spirulina is a cyanobacterium that has been commercially cultivated for more than 10 years due to its high nutritional content; e.g. protein, amino acids, vitamins, minerals, essential fatty acid and bcarotene (Meng-Umphan, 2009). Spirulina can be considered a nutritional supplement that has various health benefits for humans, and a feed supplement for animals having economic benefits. As an example, it can be a suitable food supplement when fed to trout, sea bass, fancy carp, red tilapia, shrimp and mollusk. It has been found that the alga can be used as an alternative source of protein and can also be used to improve the color, flavor and quality of meat ( $\mathrm{Lu}$ et al., 2003). Nowadays, Spirulina can be used to establish immune-potentiating functions in carp (Watanuki et al., 2006; Tongsiri et al., 2010; Mu et al., 2000 and Nandeesha et al., 2001) indicated that Spirulina could be used as an effective partially or completely replacement for fishmeal in formulated aqua feeds. Spirulina was reported to replace up to $40 \%$ of $\mathrm{FM}$ protein in tilapia (Oreochromis mossambicus) diet (Olvera-Novoa et al., 1998) and even higher replacement of FM was possible in common carp (Cyprinuscarpio) (Nandeesha et al.,1998) andon Mekong giant catfish (Pangasianodongigas) (Tongsiri et al., 2010 and Khanzadeh et al., 2016). The available nutritional data on this species are very limited up to date (Lim and Lee, 2009; Bueno Galaz et al., 2010 and Zeinab et al., 2015). The main propose of this study was to investigate effect of supplemented different levels of Spirulina from diet protein on BWG, FRC and feed intake in Nile tilapia (Oreochromis niloticus) fingerlings.

\section{MATERIALS AND METHODS}

An experiment was conducted at fish Research center in Suez Canal University Ismailia- Egypt to 
study the effect of replacement of five levels of Spirulina platensis from diet protein on growth performance and body composition of Nile tilapia (Oreochromis niloticus) fingerlings. The experiment was lasted for 56 days.

\section{Experimental diets:}

Five isonitrogenous and isocaolic diets were formulated from practical ingredients where the control diet was without Spirulina platensis $(0 \%)$ and the other four diets were replaced by 5\% (T2), $10 \%(\mathrm{~T} 3), 15(\mathrm{~T} 4) \%$ and $20 \%$ (T5) Spirulina platensis from diet protein, respectively. The composition and proximate analysis of the experimental diets are presented in Table (1and 2). The fish were hand-fed to satiation, twice/day (10 am and $4 \mathrm{pm}$ ) for 56 days. The experimental diets were formulated to contain almost $30 \%$ crude protein and gross energy $448 \mathrm{Kcal}$. $/ 100 \mathrm{~g}$. The experimental diets were prepared by individually weighing of each component and by thoroughly mixing the minerals, vitamins and additives with corn. This mixture was added to the components together with oil. Water was added until the mixture became suitable for making granules.

Table 1. Composition and proximate analysis of the experimental diets for Nile Tilapia (Oreochromis niloticus) fingerlings fed diets supplemented with different levels of Spirulina plantesis from diet protein

\begin{tabular}{|c|c|c|c|c|c|}
\hline \multirow[b]{2}{*}{ Ingredients } & \multicolumn{5}{|c|}{ Treatments } \\
\hline & $\begin{array}{c}\text { Control } \\
(\%)\end{array}$ & $\begin{array}{c}\text { Treatmen } \\
\text { T1 (5\%) } \\
(\%)\end{array}$ & $\begin{array}{c}\text { Treatment T2 } \\
(10 \%) \\
(\%)\end{array}$ & $\begin{array}{c}\text { Treatment } \\
\text { T3 (15\%) } \\
(\%)\end{array}$ & $\begin{array}{c}\text { Treatment } \\
\text { T4 (20\%) } \\
(\%)\end{array}$ \\
\hline Commercial fish meal $^{(25 \%)}$ & 5.00 & 5.00 & 5.00 & 5.00 & 5.00 \\
\hline Soybean meal & 60.00 & 57 & 55 & 52 & 48 \\
\hline Spirulina algae & 00.00 & 2.73 & 5.45 & 8.17 & 10.89 \\
\hline Yellow corn & 20.00 & 20.22 & 19.55 & 19.83 & 21.11 \\
\hline Rice bran & 9.0 & 9.0 & 9.0 & 9.0 & 9.0 \\
\hline Sun flour oil & 4.0 & 4.0 & 4.0 & 4.0 & 4.0 \\
\hline Mineral mixture $^{1}$ & 1.0 & 1.0 & 1.0 & 1.0 & 1.0 \\
\hline Vitamin mixture $^{2}$ & 1.0 & 1.0 & 1.0 & 1.0 & 1.0 \\
\hline Total & 100 & 100 & 100 & 100 & 100 \\
\hline \multicolumn{6}{|l|}{ Proximate Analysis } \\
\hline Protein & 30.60 & 30.18 & 30.72 & 30.91 & 30.75 \\
\hline Lipids & 8.10 & 8.10 & 8.10 & 8.20 & 8.2 \\
\hline Ash & 5.43 & 5.34 & 5.42 & 5.42 & 5.42 \\
\hline Fibers & 7.53 & 7.52 & 7.52 & 7.52 & 7.51 \\
\hline NFE $^{3}$ & 48.34 & 48.86 & 48.24 & 47.95 & 48.12 \\
\hline Gross energy $(\mathrm{Kcal} / \mathbf{1 0 0 g})^{4}$ & 448.11 & 447.87 & 448.37 & 449.21 & 449.00 \\
\hline Cost/Kg (L.E) & 3.65 & 3.56 & 3.50 & 3.41 & 3.29 \\
\hline \multicolumn{6}{|c|}{ 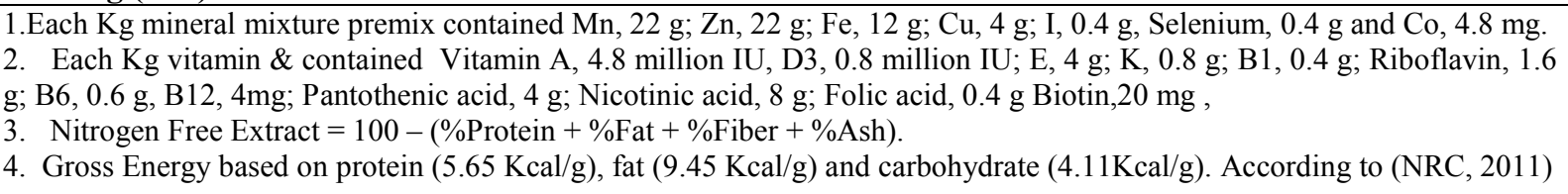 } \\
\hline \multirow{8}{*}{\multicolumn{3}{|c|}{$\begin{array}{l}\text { Chemical composition of Spirulinaused in the present } \\
\text { study was shown in Table (2). Crude protein content } \\
55 \% \text {, fat } 7 \% \text {, total carbohydrate } 21 \% \text {, fiber } 5 \% \text {, } \\
\text { Minerals } 8 \% \text { and moisture were } 4 \% \text {. The wet mixture } \\
\text { was passed through CBM granule machine with } 2 \mathrm{~mm} \\
\text { diameter. The produced pellets were dried at room } \\
\text { temperature and kept frozen until experimental start. } \\
\text { Water temperature and dissolved oxygen was } \\
\text { determined by Metteler Toledo, model } 128 . \mathrm{s} / \mathrm{No} 1242 \\
\text { where the average range of temperature } 25.30 \pm 1.7 \\
{ }^{\circ} \mathrm{C} \text { and dissolved oxygen was above } 4.7 \pm 0.5 \mathrm{mg} / 1 \text {. } \\
\text { other water quality including pH and ammonia were } \\
\text { measured every two days by pH meter (Orion model } \\
720 \mathrm{~A} \text {, s/no 13062) and ammonia meter by Hanna } \\
\text { ammonia meter where the average range of ammonia }\end{array}$}} & \multicolumn{3}{|c|}{$\begin{array}{l}\text { was } 0.07 \pm 0.001 \mathrm{mg} / \mathrm{l} \text { and } \mathrm{pH} \text { was ranged in } 7.7 \pm 0.7 \\
\text { throughout the experimental period (Table } 3 \text { ). All } \\
\text { water quality parameters within the accepted levels } \\
\text { for Nile tilapia (Boyd, 1984). } \\
\text { Table 2. The chemical analysis of Spirulina. } \\
\text { Platensis }\end{array}$} \\
\hline & & & Component & \multicolumn{2}{|c|}{ Concentration (\%w/w) } \\
\hline & & & Crude protein & \\
\hline & & & Fat (lipids) & \\
\hline & & & $\begin{array}{l}\text { Total } \\
\text { carbohydrate }\end{array}$ & \multicolumn{2}{|c|}{21} \\
\hline & & & Fiber & \\
\hline & & & Minerals & \multicolumn{2}{|c|}{0} \\
\hline & & & Moisture content & \multicolumn{2}{|c|}{4} \\
\hline
\end{tabular}


Table 3. Water quality parameters (Mean \pm SD)

\begin{tabular}{|c|c|c|c|c|c|}
\hline \multirow[b]{2}{*}{ Item } & \multicolumn{5}{|c|}{ Treatments } \\
\hline & Control $^{*}$ & $\mathbf{T} 1^{*}$ & $\mathrm{~T} 2^{*}$ & $\mathrm{T3}^{*}$ & $\mathrm{T4}^{*}$ \\
\hline Temperature $\left({ }^{\circ} \mathrm{C}\right)$ & $25.30 \pm 1.7$ & $25.30 \pm 1.7$ & $25.30 \pm 1.7$ & $25.30 \pm 1.7$ & $25.30 \pm 1.7$ \\
\hline $\operatorname{Oxygen}(\mathrm{mg} / \mathrm{L})$ & $4.7 \pm 0.50$ & $4.7 \pm 0.50$ & $4.7 \pm 0.50$ & $4.7 \pm 0.50$ & $4.7 \pm 0.50$ \\
\hline Ammonia (mg/l) & $0.07 \pm 0.01$ & $0.07 \pm 0.01$ & $0.07 \pm 0.01$ & $0.07 \pm 0.01$ & $0.07 \pm 0.01$ \\
\hline pH & $7.7 \pm 0.72$ & $7.7 \pm 0.74$ & $7.7 \pm 0.74$ & $7.7 \pm 0.72$ & $7.7 \pm 0.72$ \\
\hline
\end{tabular}

*Note: Control diet was without Spirulina platensis $(0 \%)$ and T1,T2,T3 and T4 were replaced by 5\%,10\%,15\% and $20 \%$

Spirulina platensis from diet protein, respectively

\section{Experimental unit:}

Fish were stocked in 15 rectangle plastic tank $(80 \mathrm{~cm} \times 60 \mathrm{~cm} \times 60 \mathrm{~cm})$ and were randomly divided into four equal experimental groups (20 fish each treatment, three replicate/tanks). Tanks supplied with air blowers. Photoperiod was $12 \mathrm{~h}$ light/ $12 \mathrm{~h}$ dark. Water temperature was maintained at $\left(25 \pm 1{ }^{\circ} \mathrm{C}\right)$ by using a 250 watt immersion heater with thermostat. The tank water was exchanged with fresh water 2-3 time/week. Tanks were washed and changed with fresh water every four weeks.

\section{Experimental fish:}

Nile tilapia fingerlings (Oreochromis niloticus) fingerlings were used in this study with mean average initial weight of $9.9 \pm 0.02 \mathrm{~g}$ were obtained from Fish Research Center, Suez Canal University. Fish were homogenous in body weights and apparently healthy. Fish were acclimated to laboratory conditions for 2 weeks prior before the experiment study.

\section{Experimental Methodology: Samples of fish:}

At the start and the end of the main experimental period (56 day), 5 fish were randomly taken from each experimental group. Fish were used for chemical analysis of the whole body. The tested diets and body were analyzed for crud protein (CP \%) ether extract (EE \%), crude fiber (CF \%), ash (\%) and moisture. The whole body composition of fish samples were analyzed except crud fiber (CF \%) according to the procedures described by standard A. O. A. C. methods (1995). The nitrogen free-extract (NFE \%) was calculated by differences.

Fish were individually weighed every two weeks by UWE MJW-300 balance to the nearest $0.01 \mathrm{~g}$. The amount of diet was readjusted according to the new weight of fish.

\section{Growth performance parameters:}

The growth performance parameters are calculated according to the following equations:

\section{Average Weight Gain (AWG): \\ $(\mathrm{AWG})=$ Average final weight $(\mathrm{g})-$ Average initial weight $(\mathrm{g})$}

\section{Average Daily Gain (ADG):}

$(\mathrm{ADG})=[$ Average final weight $(\mathrm{g})-$ Average initial weight (g)] / time (days)

\section{Specific Growth Rate (SGR \%/day):}

$(\mathrm{SGR} \% /$ day $)=100[\mathrm{Ln} \mathrm{Wt1}-$ Ln Wt. 0 / t]

Where: - Ln: normal log Wt. 0: initial weight (g).
Wt. 1: final weight $(\mathrm{g}) \quad \mathrm{T}$ : time of days. Feed and protein utilization parameters:

Feed and protein utilization parameters are calculated according to the following equations:

Feed Conversion Ratio (FCR):

$\mathrm{FCR}=$ Total feed consumption/ weight gain.

Feed Efficiency (FE):

$\mathrm{FE}=$ weight gain/ Total feed consumption

Survival (\%):

$$
\mathrm{SR}=\mathrm{Ni} \times 100 / \mathrm{N} 0
$$

\section{Where:}

$\mathrm{Nt}=$ Total number of fish survived in tank at end of experiment.

$\mathrm{N} 0=$ Total number of fish survived in tank at beginning of experiment.

\section{Blood parameters:}

Blood samples were collected at the end of experiment; fish in each aquarium were weighted and 5 fish were taken randomly for blood sampling. After transferring Eppendorf tubes containing $4 \mathrm{ml}$ blood to laboratory and allowed to clot at room temperature. Separation of serum from blood cells was carried out by centrifuge (Model 200 Labofuge, Heraeussepatch Company, made in Germany) in $3000 \mathrm{rpm}$ for 5 minutes. Then using Pastor Pipette, serum was transferred to marked Eppendorf and was maintained in $-20{ }^{\circ} \mathrm{C}$ until measurement (Pottinger and Carrick, 2001) for total protein, albumin, triglycerides, The activities of aspartate aminotransferase (AST) and alanine aminotransferase (ALT) were carried out using Colorimetric method, Roch Diagnostics, GmbH, Monnheim, Germany kits according to (Reitman and Frankel, 1957). Serum total protein $(\mathrm{g} / \mathrm{dl})$ and albumin $(\mathrm{g} / \mathrm{dl})$ were determined calorimetrically using kits supplied by Elnasr Pharmaceutical Chemicals Co. (Egypt). Serum globulin $(\mathrm{g} / \mathrm{dl})$ levels were obtained by differences between total protein $(\mathrm{g} / \mathrm{dl})$ and albumin $(\mathrm{g} / \mathrm{dl})$. Serum triglycerides $(\mathrm{mg} / \mathrm{dl})$ were determined calorimetrically using commercial kits of Biodiagnostic Co. (Egypt). Urea was determined by urea Assay kit. Creatinine was determined according to (Pincus, 1996).

\section{Statistical analysis:}

The data obtained in this study were analyzed by one-way ANOVA procedure of Statistical Analysis System (SAS, 2000). Means were compared by Duncan's new multiple ranges test Duncan (1955).

Where: 
$Y_{i j}=\mu+D_{i}+e_{i j}$

$Y_{i j}=$ the observation of the $j^{\text {th }}$ individual from $D^{\text {th }}$ Diet.

$\mu=$ the overall mean. $\quad D_{i}=$ The Fixed effect of the $\mathrm{D}^{\text {th }}$ Diet.

$\mathrm{e}_{\mathrm{ij}}=$ The random error associated with the individual $\mathrm{j}$.

\section{Economical Evaluation:}

The cost of feed to raise unit biomass of fish was estimated by a simple economic analysis. The estimation was based on local retail sale market price of all the dietary ingredients at the time of the study.

Cost $/ \mathrm{kg}$ diet $(\mathrm{LE})=$ Cost per $\mathrm{Kg} \operatorname{diet} \mathrm{L}$.E.

Consumed feed to produce $1 \mathrm{~kg}$ fish $(\mathrm{kg})=$ Feed intake per fish per period/ final weight per fish $\mathrm{Kg} / \mathrm{Kg}$

Feed cost per kg fresh fish (LE) = Step 1X step 2

Relative $\%$ of feed cost $/ \mathrm{kg}$ fish $=$ Respective figures for step 3/ highest figure in this step

Feed cost $/ 1 \mathrm{Kg}$ gain $(\mathrm{LE})=$ Feed intake per $\mathrm{Kg}$ gain X step 1

Relative \% of feed cost of $\mathrm{Kg}$ gain = Respective figures for step $5 /$ highest figure in this step

*Cost of $1 \mathrm{~kg}$ ingredients used were $3.50 \mathrm{~L} . \mathrm{E}$, Egypt

Feed Ingredients Price at start of 2014.

\section{RESULTS AND DISCUSSION}

\section{Growth Performance:}

The effects of Spirulina supplementation on growth performance and feed utilization of Nile Tilapia (Oreochromis niloticus)fingerlings fed tested diets is presented in Table (4). No significant differences $(\mathrm{P}<.05)$ in initial body weight were found among the different experimental treatments, indicating the accuracy of randomization process between the experimental treatments. It was observed that groups of fish fed the diet containing Spirulina showed higher values of body weight, weight gain, relative growth rate (RGR.), specific growth (SGR.), compared to the group of fish fed with the diet without Spirulina (control group) .

Significant difference $(P<0.05)$ in BWG levels between the dietary groups compare to the control which all treatments had higher BWG compare to the control treatment during all experimental period $(P<0.05)$. Specific growth rate (SGR) is the measuring tools reflecting the fish health status under natural and experimental conditions. In the current study dried $S$. platensis found to be of potential effects on growth at an optimum replacement of $20 \%$. Its worth mentioned that the mean value level in the group received $20 \%$ was higher in all the tested parameters with significant difference $(\mathrm{P}<0.05)$ (Table, 4) to enhance growth performance. (Duncan and Klesius, 1996) reported that Spirulina alga was a good source of protein for animal feed, being containing high amounts of vitamins and minerals, in addition, (Nakono et al., 2003). Olvera-Novoa et al., (1998) reported that Spirulina can replace up to $20 \%$ of FM protein in diets for O. mossambicus, but reduced growth and feed utilization were observed at higher replacement levels to 100 and $60 \%$ by Spirulina in diets for C. carpio and Siberian sturgeon (Acipenserbaeri), respectively, without any adverse effects (Nandeesha et al., 1998 and Palmegiano et al., 2005). Other studies suggested that dietary FM can be replaced up to 100 and $60 \%$ by Spirulina in diets for $C$. Carpio ; Siberian sturgeon (Acipenserbaeri) and Nile tilapia, respectively, without any adverse effects (Nandeesha et al., 1998; Palmegiano et al., 2005 and El-Sheekh et al., 2014).

Table 4. Growth performance and feed utilization (of Nile tilapia (Oreochromis niloticus) fingerlings fed diets supplemented with different levels of Spirulina

\begin{tabular}{|c|c|c|c|c|c|}
\hline \multirow[b]{2}{*}{ Items } & \multicolumn{5}{|c|}{ Spirulina levels (\%) } \\
\hline & $\begin{array}{c}\text { Control }^{*} \mathrm{~T} 1 \\
(0 \%)\end{array}$ & $\begin{array}{c}T^{*} 2^{*} \\
(5 \%)\end{array}$ & $\begin{array}{c}T 3^{*} \\
(10 \%)\end{array}$ & $\begin{array}{c}T 4^{*} \\
(15 \%)\end{array}$ & $\begin{array}{c}T 5^{*} \\
(20 \%)\end{array}$ \\
\hline Initial weight (g) & $9.91 \pm 0.11$ & $9.89 \pm 0.10$ & $9.90 \pm 0.11$ & $9.92 \pm 0.12$ & $9.91 \pm 0.14$ \\
\hline Final weight (g) & $17.20^{\mathrm{e}} \pm 0.12$ & $18.90^{\mathrm{d}} \pm 0.10$ & $21.60^{c} \pm 0.13$ & $26.50^{\mathrm{b}} \pm 0.10$ & $28.20^{\mathrm{a}} \pm 0.11$ \\
\hline Weight gain (g) & $7.29^{\mathrm{e}} \pm 0.10$ & $9.01^{\mathrm{d}} \pm 0.10$ & $11.70^{\mathrm{c}} \pm 0.10$ & $16.58^{\mathrm{b}} \pm 0.10$ & $18.29^{\mathrm{a}} \pm 0.10$ \\
\hline Weight gain $(\%)$ & $73.56^{\mathrm{e}} \pm 0.10$ & $91.10^{\mathrm{d}} \pm 0.10$ & $118.30^{\mathrm{c}} \pm 0.10$ & $167.71^{\mathrm{b}} \pm 0.10$ & $184.56^{\mathrm{a}} \pm 0.10$ \\
\hline Specific growth rate (\%/day) & $1.24^{\mathrm{d}} \pm 0.11$ & $1.15^{\mathrm{e}} \pm 0.12$ & $1.40^{\mathrm{c}} \pm 0.15$ & $1.76^{\mathrm{b}} \pm 0.14$ & $1.87^{\mathrm{a}} \pm 0.11$ \\
\hline Feed intake (g feed/fish) & $18.75^{\mathrm{e}} \pm 0.10$ & $21.53^{\mathrm{d}} \pm 0.12$ & $25.62^{c} \pm 0.14$ & $35.83^{\mathrm{a}} \pm 0.11$ & $33.43^{\mathrm{b}} \pm 0.12$ \\
\hline Food conversion ratio & $2.57^{\mathrm{e}} \pm 0.10$ & $2.39^{\mathrm{d}} \pm 0.11$ & $2.19^{c} \pm 0.13$ & $2.16^{\mathrm{b}} \pm 0.10$ & $1.83^{\mathrm{a}} \pm 0.14$ \\
\hline Protein efficiency ratio & $1.27^{\mathrm{d}} \pm 0.10$ & $1.36^{\mathrm{e}} \pm 0.11$ & $1.49^{c} \pm 0.13$ & $1.50^{\mathrm{b}} \pm 0.14$ & $1.78^{\mathrm{a}} \pm 0.11$ \\
\hline Feed efficiency & $0.38^{\mathrm{d}} \pm 0.10$ & $0,42^{\mathrm{c}} \pm 0.13$ & $0.45^{\mathrm{b}} \pm 0.11$ & $0.46^{\mathrm{b}} \pm 0.11$ & $0.55^{\mathrm{e}} \pm 0.13$ \\
\hline Survival rate $(\%)$ & $98.00^{\mathrm{a}} \pm 0.80$ & $98.00^{\mathrm{a}} \pm 0.80$ & $98.00^{\mathrm{a}} \pm 0.70$ & $98.00^{\mathrm{a}} \pm 0.60$ & $98.00^{\mathrm{a}} \pm 0.10$ \\
\hline
\end{tabular}

Means \pm SD in the same letters in the same row is not significantly different at $\mathrm{P}<0.05$.

*Note: Control diet was without Spirulina platensis $(0 \%)$ and T1,T2,T3 and T4 were replaced by $5 \%, 10 \%, 15 \%$ and $20 \%$ Spirulina platensis from diet protein, respectively.

Growth enhancement effect of Spirulina is attributed to its role in nutrient digestibility and its high contents of several nutrients, such as vitamins and minerals (Abdel-Tawwaband Ahmad, 2009 and Velasquez and Ragaza, 2015). Negative effects of high dietary inclusion levels of Spirulina on fish growth can be resulted from reduced phosphorous availability and decreased feed palatability (OlveraNovoa et al., 1998). The variations in Spirulina effects on fish growth performance are ascribed to different nutrient content of Spirulina species used in the studies (Nandeesha et al., 1998). Nandeesha et 
al. (2001) found that FM can be totally replaced with Spirulina in diets for rohu $\operatorname{carp}($ Labeo-rohita) and even significant higher growth can be obtained compared to the use of FM as the sole protein source, whereas nosignificant effect was observed on growth performance of catla (Catlacatla) by the same Spirulina supplemented diets. Such differences in growth response of $L$. rohita and $C$. catlato dietary Spirulina were clearly showed that the growth response of fishes to Spirulina is likely to be speciesspecific. The other significant factor that affects the results of Spirulina administration is the composition of experimental diets in which Spirulina is incorporated (Takeuchi et al., 2002). Another study was conducted in which $10-15 \%$ Spirulina alga replaced crushed fish in the feed given to Red Tilapia fish in order to bring the protein level up to $30 \%$ and this yielded the highest average daily growth rate and specific growth rate, in the Tilapia (Promya et al., 2003). Similar research was done by Promya and Hongwittayakorn (2003) in which Spirulina and Cladophora algae were fed to fancy Carp fingerlings. The study reported that, the fish received the Spirulina powder demonstrated a higher average daily growth rate, weight gain rate, survival rate, than the fancy Carp that were fed with standard feed and feed mixed with Cladophora.

Research conducted by Duncan and Klesius (1996) found that Spirulina alga was a good source of protein for animal feed, as well as containing high amounts of vitamins and minerals. The cellular structure of Spirulina algae is easily digestible and containsa little bit cellulose.

The feed conversion rate, PER, FR and biomass gain of Nile tilapia fingerlings are reported in (Table 4). The growth performance showed that Spirulina promotes growth better than the control diet, and in particular $20 \%$ inclusion seems to be the best performance: a high biomass increase and growth rate, the best feed conversion rate and a high PER. The results are in agreement with El-Sheekh et al. (2014) and, Zeinab et al. (2015).

The average values of FCR show a significant $(\mathrm{P}<0.05)$ different between all treatments. The group of fish on $\mathrm{T} 4$ had significant $(\mathrm{P}<0.05)$ lower FCR (1.83), while the group of fish on control had the highest FCR (2.40). The results in the current study are in accordance with Watanabe et al. (1990) and Takeuchi, et al. (2002) who found that feed supplemented with $S$. platensis powder improved the feed conversion ratio and growth rates in striped jack, Pseudocaranxdentex. Lu et al. (2002) demonstrated that raw $S$. platensis can be an effective -feed for larval tilapia at a feeding rate of $30 \%$ (on a dry basis) of body weight. Abdel-Tawwab and Ahmed (2009) recorded that the growth and feed utilization of O.niloticus were obtained at $5.0 \mathrm{~g}$ fresh culture of $S$. platensis $/ \mathrm{kg}$ diet. Our results show that, treatments with Spirulina platensis had feed conversion ratios $(\mathrm{FCR})$ significantly $(\mathrm{P}<0.05)$ lower than those for the control diets. The best conversion ratio (1.83) was recorded for the $20 \%$ diet of Spirulina platensis treatments. It is proved that lower the feed conversion ratio higher is the quality of the feed as observed in many fresh water fishes where the feed conversion ratio is known to decrease with increasing dietary protein content (Jha et al., 2009 and Zeinab et al., 2015). Similar results have been reported for feed additives used in diets for piglets (Gil, 1998). Moreover, the group of fish on T4 had significantly $(\mathrm{P}<0.05)$ higher PER, FI and FE while the group of fish on control had the lowest PER, FI and FE, this agree with the finding of Badwy et al. (2008) the incorporation $50 \%$ algae replacement resulted in the significant greater value of FCR $(2.03 \pm 0.08$ and $1.76 \pm 0.05)$, respectively. These results are agreed with those obtained by Dawah et al. (2002) and Jha et al.(2009). Who found that food conversion ratio and PER were better when the fish were maintained on artificial diets with $10 \%$ and $20 \%$ dried algae. In addition, Zeinhom (2004) found that, Inclusion of algae in fish diets insignificantly $(\mathrm{P}<0.05)$ improved the FCR (1.83), PER and (1.76), whereas feed intake was significantly $(\mathrm{P}<0.05)$ increased $(33.47 \mathrm{~g})$ Table (4). However, these results are good agreement with those obtained by Hayashi et al. (1998) and AbuZead (2001) who found that the protein efficiency ratio ranged from 1.1 to 1.7 for Nile tilapia and common carp fed on diets containing aquatic plant and algae, while Ibrahim et al. (2007) reported that, feed conversion ratio gradually increased with increasing Azolla meal percentage in the diets without significant differences until $31.8 \%$ inclusion level after that, significantly $(\mathrm{P}<0.05)$ decreased, they added that, economical feed efficiency improved as the level of the dietary Azolla meal increased from 10.6 to $31.8 \%$ of the diet. Duncan and Klesius (1996) reported that Spirulina alga was a good source of protein for animal feed, being containing high amounts of vitamins and minerals, in addition, Nakono et al. (2003) recorded that the lack of cellulose from the cellular structure of Spirulina render it easily digestible, thus, increase fish appetite, improve feed intake and nutrient digestibility and in turn enhance the health of fish, increasing the ability to fight off infections through the reduction of stress levels. The results in the current study are in accordance with Watanabe et al. (1990) and Takeuchi et al. (2002) who found that feed supplemented with $S$. platensis powder improved the feed conversion ratio and growth rates in striped jack, Pseudocaranxdentex. Lu et al. (2002) demonstrated that raw $S$. platensis can be an effective -feed for larval tilapia at a feeding rate of $30 \%$ (on a dry basis) of body weight. Abdel-Tawwab and Ahmed (2009) recorded that the growth and feed utilization of O.niloticus were obtained at $5.0 \mathrm{~g}$ fresh culture of $S$. platensis $/ \mathrm{kg}$ diet. Treatments with Spirulina platensis had significant $(\mathrm{P}<0.05)$ feed conversion ratios (FCR) lower than those for the control diets. 
The best conversion ratio (1.83) was recorded for the $20 \%$ diet of Spirulina platensis treatments. The lower feed conversion ratio the higher is the quality of the feed as observed in many fresh water fishes where the feed conversion ratio is known to decrease with increasing dietary protein content (Jha et al., 2009 and Zeinab et al., 2015).Similarresults have been reported for feed additives used in diets for piglets (Gil, 1998).Moreover, the group of fish on T5 had significant $(\mathrm{P}<0.05)$ higher $\mathrm{PER}, \mathrm{FI}$ and $\mathrm{FE}$, while the group of fish on the T1 had the least PER, FI and $\mathrm{FE}$, this agreed with the finding of Badwy et al. (2008) who reported that, the incorporation $50 \%$ algae replacement resulted in the significant greater valueof FCR $(2.03 \pm 0.08$ and $1.76 \pm 0.05)$ respectively. These results are agreed with those obtained by Dawah et al. (2002) and Jha et al. (2009) who found that food conversion ratio and PER were better when the fish were maintained on artificial diets with $10 \%$ and $20 \%$ dried algae. In addition, Zeinhom (2004) found that, inclusion of algae in fish diets insignificantly $(\mathrm{P}<0.05)$ improved the FCR (1.83), PER and (1.76), whereas feed intake was significantly $(\mathrm{P}<0.05)$ increased $(33.47 \mathrm{~g})$ (Table, 4$)$. However, these results are in good agreement with those obtained by Hayashi et al. (1998) and AbuZead (2001) who found that the protein efficiency ratio ranged from 1.1 to 1.7 for Nile tilapia and common carp fed on diets containing aquatic plant and algae. Ibrahimet al.(2007) reported that, feed conversion ratio gradually increased with increasing Azolla meal percentage in the diets without significant differences until $31.8 \%$ inclusion They added thateconomical feed efficiency improved as the level of the dietary Azolla meal increased from 10.6 to $31.8 \%$ of the diet. Duncan and Klesius (1996) reported that Spirulina alga was a good source of protein for animal feed, and contained high amounts of vitamins and minerals. Nakono et al. (2003) recorded that the small amount of cellulose from the cellular structure of Spirulina render it easily digestible, and increase fish appetite, improve feed intake and nutrient digestibility and in turn enhance the health of fish, increasing the ability to fight off infections through the reduction of stress levels. The results in the current study are in accordance with Watanabe et al. (1990) and Takeuchi et al. (2002) who found that feed supplemented with $S$. platensis powder improved the feed conversion ratio and growth rates in striped jack, Pseudocaranxdentex. Lu et al. (2002) demonstrated that raw S. platensis can be an effective feed for larval tilapia at a feeding rate of $30 \%$ (on a dry basis) of body weight. This contributes to optimizing protein use for growth, a significant quality given that protein is the most expensive feed nutrient. The improvement in the biological value of the supplemented diets in these treatments with high population and low dietary protein demonstrated that Spirulina supplements performed more efficiently in stress situations (Ringo and Gatesoupe, 1998).No significant differences in fish survival among the different treatments $(\mathrm{P}<0.05)$, and its $98 \%$ (Table 4). Some studies have shown that feeding Spirulina to fish could improve their survival rate and growth rate (Belay et al., 1996; Hayashi et al., 1998 and Tongsiri et al., 2010).

\section{Fish body composition:}

Spirulina significantly $(\mathrm{P}<0.05)$ was affected whole-fish body composition (Table 5). Fish fed the control diet had the lowest protein content; however, all feed replacement with Spirulina appeared to improve their protein bodycontent. Carcass lipid content was also affected by dietary treatments, being the highest in the group T4, which were statistically $(\mathrm{P}<0.05)$ the highest than the rest of dietary replacement treatments. The supplementation of live Spirulina significantly $(\mathrm{P}<0.05)$ affected the protein and lipid contents in the whole-fish body. The better feed intake of Spirulina diets may be due to the increased fish appetite, resulting in a higher feed intake and improved growth. On the other hand, changes in the protein and lipid contents in the fish body could be linked to changes in their synthesis, deposition rate in muscle and/or different growth rates, high feed intake and nutrient utilization,( Abdel-Tawwab and Ahmad, 2009). These results agreed with Soivio et al. (1989) who concluded that the differences in protein content of fish body composition may be related to changes in their synthesis, deposition rate inmuscle and/or different growth rate.

Table 5. Body chemical composition of Nile tilapia (Oreochromis. niloticus) fingerlings fed diet supplemented with different levels of Spirulina on dry matter basis

\begin{tabular}{ccccc}
\hline \multirow{2}{*}{$\begin{array}{c}\text { Chemical } \\
\text { Composition }\end{array}$} & Moisture (\%) & Crude protein (\%) & Ether extract (\%) & Ash (\%) \\
\cline { 2 - 5 } & $73.4 \pm 0.27$ & $61.2 \pm 0.27$ & $22.8 \pm 0.27$ & $16.6 \pm 0.27$ \\
\hline Initial & $72.5^{\mathrm{a}} \pm 0.27$ & $62.2 \mathrm{c} \pm 0.32$ & $23.1 \mathrm{c} \pm 0.18$ & $14.7 \mathrm{a} \pm 0.13$ \\
Control $^{*}$ & $72.5^{\mathrm{a}} \pm 0.22$ & $62.6 \mathrm{c} \pm 0.40$ & $23.7 \mathrm{c} \pm 0.12$ & $13.7 \mathrm{~b} \pm 0.23$ \\
T1 $^{*}$ & $72.5^{\mathrm{a}} \pm 0.25$ & $63.3 \mathrm{~b} \pm 0.21$ & $23.8 \mathrm{c} \pm 0.14$ & $12.9 \mathrm{c} \pm 0.22$ \\
T2 $^{*}$ & $72.5^{\mathrm{a}} \pm 0.22$ & $63.7 \mathrm{~b} \pm 0.41$ & $24.1 \mathrm{~b} \pm 0.16$ & $12.2 \mathrm{c} \pm 0.20$ \\
T3 $^{*}$ & $72.5^{\mathrm{a}} \pm 0.24$ & $64.5 \mathrm{a} \pm 0.51$ & $25.5 \mathrm{a} \pm 0.18$ & $11.0 \mathrm{e} \pm 0.22$ \\
T4 $^{*}$ & &
\end{tabular}


The lowest feed cost per $\mathrm{kg}$ fresh fish $(3.92 \mathrm{LE})$, Relative $\%$ of feed cost $/ \mathrm{kg}$ fish $(85 \%)$, Feed cost $/ 1 \mathrm{Kg}$ gain(6.02 LE) and Relative \% of feed cost of $\mathrm{Kg}$ gain (57\%) in group of fish fed diet 4 (20\% Spirulina). This indicates that treatment 4 which supplemented with $20 \%$ Spirulina is most economic than the rest of dietary treatments.

In conclusion, this study demonstrates that up to $20 \%$ of Spirulina were most effective in stimulating fish growth and more economic for Nile tilapia (Oreochromis niloticus) fingerlings under the experimental condition.

\section{REFERENCES}

A.O. A. C. Methods, 1995. AOAC. (Association of Official Analytical Chemists), Official Methods of Analysis. Washington DC.

Abdel-Tawab, M., M.H. Ahmad, Y.M. Abdel- Hadi, and M.E.A. Sedan, 2008. Use of Spirulina (Arthrospira platensis) as a growth and immunity promoter for Nile tilapia, Oreochromis niloticus (L.) FRY challenged with pathogenic Aeromonashydrophila. International Symposium on Tilapia in Aquaculture, 188 - 188.

Abdel-Tawwab, M. and H. Ahmad, , 2009. Live Spirulina (Arthrospira platensis) as a growth and immunity promoter for Nile tilapia, Oreochromis niloticus (L.), challenged with pathogenic Aeromonashydrophila. Aquaculture Res.; 40(9):1037-1046.

Abu-Zead, M. Y., 2001. Studies on some plants used for fish nutrition. Ph.D. Thesis. Faculty of Agriculture, AL-Azhar University, Egypt.

Badawy, T. M., E. M. Ibrahim, and N.M. Zeinhom, 2008. Partial replacement of fishmeal with dried microalgae Chlorella spp. and Scenedesmus spp.) In Nile Tilapia (Oreochromis niloticus) diets. 8th International Symposium on Tilapia in Aquaculture.

Belay, A., T. Kato, and Y. Ota, 1996. Spirulina (Arthrospira): potential application as an animal feed supplement. Journal of Applied Phycology 8: 303-311, 1996. 303.

Boyd, C. E., 1984. Water Quality in Warm water Fishponds. Auburn University Agriculture Experimental Station, Auburn, AL, USA.. (Oncorhynchustshawytscha) and rainbow trout (Oncorhynchusmykiss). Aquaculture 161: 27-43.

BuenoGalaz, G.; S.S. Kim and K.J., Lee, 2010. Effects of different dietary vitamin $\mathrm{E}$ levels on growth performance, non-specific immune responses, and disease resistance against Vibrio Anguilla rumin parrot fish (Oplegnathusfasciatus). Asian-Australasian Journal of Animal Science, 23: 916-923.

Dawah, M. A.; A. M Khater,.; I. M. A, Shaker and N.A., Ibrahim., 2002. Production of Scenedesmus Bijuga (Chlorophyceae) in large scale in outdoor tanks and its use in feeding monosex Nile tilapia (Oreochromis niloticus) fry. J. Egypt. Acad. Soc. Environ. Develop. (B. Aquaculture) 2 (1): 113125.

Duncan, D. B., 1955. Multiple ranges and multiple Ftest. Biometrics, 11:1- 42.

Duncan, P. L. and P. H., Klesius, 1996. Effects of feeding Spirulina on specific and non-specific immune responses of channel catfish. J. Aquat. Animal Health, 8: 308-313.

El-Hindawy, M. M.; M. A Abd-Razic.; H. A. Gaber, and M. M, Zenhom, 2006. Effect of various levels of dietary algae ScenedesmusSpp on physiological performance and digestibility of Nile tilapia fingerlings. $1^{\text {st }}$ Scientific Conference of the Egyptian Aquaculture Society. Sharm ElSheikh - Sinai, Egypt, pp 137-149.

El-Sayed, A.F. M., 2006. Tilapia Culture. CABI publishing, CABI International Willingford, Oxford shire, UK.

El-Sheekh, M. I.; I. El-Shourbagy ; S.Shalaby and S.Hosny, 2014. Effect of Feeding Arthrospira platensis (Spirulina) on Growth and Carcass Composition of Hybrid Red Tilapia (Oreochromis niloticus $x$ Oreochromis mossambicus). Turkish Journal of Fisheries and Aquatic Sciences 14: 471-478.

Gil, F., 1998. Empleo de enzimas en nutricio'n animal. Pharmaceuticals from cultured algae. J. Ind. Microbiol. 5:113-124.

Hayashi, O.T.; T.Hirahashi ; H.Katoh,; T. Miyajima Hirano and Y. Okuwaki, 1998. Class specific influence of dietary Spirulina plantesison antibody production in mice. J. Nutr. Sci. Vitaminol., 44: 841-851.

Ibrahim, M. S.; M. M. Zeinhom, and R. A. Abou-Seif ,2007. Response of Nile tilapia (Oreochromis niloticus) fingerlings to diets containing azolla meal (dried pellet form). Arabian aquaculture society journal, 2 (1): 54-69.

Jha, G.; T. Tiwari,; K.Borana, and T.Qureshi, 2009. Growth, survival and dietary utilization of gold fish fed on formulated feeds with different protein level. Proceeding of RAEP (2009) International conference and exhibition; Agra, India. pp. 453458.

Khanzadeh, M.; A.E. Fereidouni ; A. Esmaeili, and S.S. Berenjestanaki, 2016. Effects of partial replacement of fish meal with Spirulina platensis meal in practical diets on growth, survival, body composition and reproductive performance of three-spot gourami (Trichopodustrichopterus) (Pallas, 1770). Aquaculture International, 24, (1), pp. 69-84.

Lim, S.J. and K.J. Lee, , 2009. Partial replacement of fish meal by cottonseed meal and soybean meal with iron and phytase supplementation for parrot fish Oplegnathusfasciatus. Aquaculture, 290: 283-289. 
Lu, J.; T.Takeuchi, and H. Ogawa, 2003. Flesh quality of tilapia Oreochromis niloticus fed solely on raw Spirulina. Fisheries Science, 69: pages 529-534.

Lu, J.; G.Yoshizaki; K.Sakai, and T.Takeuchi, , 2002. Acceptability of raw Spirulina platensis by larval tilapia Oreochromis niloticus. Fisheries Science $68,51-58$.

Meng-Umphan, K., 2009. Growth Performance, Sex Hormone Levels and Maturation. Maejo International Journal of Science and Technology, 2 (03), 559-567.

Metwalli, A. A., 2013. Effects of partial and total substitution of fish meal with corn gluten meal on growth performance, nutrients utilization and some blood constituents of the Nile tilapia (Oreochromus niloticus). Egypt J. Aqua Biol. and Fish17: 91-100.

Mu, Y.Y.; T.J. Lam, and K.L.Shim, , 2000. Protein digestibility and amino acid availability of several protein sources for juvenile Chinese hairy crab, Eriocheirsinensis H. Milne -Edwards (Decapodagrapsidae) Aquaculture Research 31 (10): 757-765.

Nakono, T.; T.Yamaguchi,; M.Sato and Iwama, G., 2003. Biological Effects of Carotenoids in Fish. International Seminar Effective Utilization of Marine Food Resource, Songkhla, Thailand, 2003, 1-15.

Nandeesha, M.C.; B. Gangadhara; J.K. Manissery, and L.V. Venkataraman,., 2001. Growth performance of two Indian major carps, catla(Catlacatla) and rohu (Labeorohita) fed diets containing different levels of Spirulina platensis. Bio-resour Technol.; 80(2):117-20.

Nandeesha, M. C.; B. Gangadhara; T. J. Varghese and Keshavanath, P. , 1998. Effect of feeding Spirulina platensis on the growth, proximate composition and organoleptic quality of common carp, Cyprinuscarpio. Aqua cult. Res., 29: 305312.

National Research Council, 2011. Nutrition requirements of fish. National Academy Press Washington DC., U.S.A.

Olvera-Novoa, M.A.; L. J. Domínguez -Cen ; L. Olivera- Castillo, and C.A. Martínez -Palacios, C.A., 1998. Effect of the use of the microalga Spirulina maxima as fish meal replacement in diets for tilapia, Oreochromis mossambicus (Peters), fry. Aqua cult. Res., 29: 709-715.

Palmegiano, G.B.; E. Agradi ; G. Forneris,; F.Gai, L . Gasco; E. Rigamonti; B. Sicuro and I. Zoccarato, 2005. Spirulina as a nutrient source in diets for growing sturgeon (Acipenserbaeri). Aquaculture Research, 16:188-195.

Pincus, M., 1996. Interpreting laboratory results: reference values and decision making, In: Henry, J.B. (Ed.), Clinical Diagnosis and Management by Laboratory Methods, Nineteenth edition. W.B. Saunders, Philadelphia. PA. USA. pp. 74-91.
Pottinger, T. G. and T. R. Carrick, 2001. Stress responsiveness affects dominant-subordinate relationships in rainbow trout. Hormones and Behavior 40:419-427.

Promya, V; N. Pugh; S.A. Ross; H.N. Elsohly ; M.A. Elsohly and D.S. Pasco, 2003. Isolation of three weight polysaccharide preparations with potent immune stimulatory activity from Spirulina platensis, Aphanizomenonflos - aguae and Chlorella pyrenoidosa. PlantaMedica, 67: 737742.

Promya, J. and P. Hongwittayakorn, 2003. Using Spirulina platensis Alga to Improve Coloring of Fancy Carp Fish. The First Alga and Plankton Academic Conference, Meeting Hall 10, 50 years IT Building, Kasetsart University, Bangkok, Thailand.

Reitman, A. and S. Franks, , 1957. Determination of aspartate glutamic amino transferees and alanineaminotransferase. American Journal of Clinical Pathology. 1957 Nov; 10 (4): 394-399.

Ringo, E. and F. Gatesoupe, , 1998. Lactic acid bacteria in fish: a review. Aquaculture 160:177203.

S. A. S. Statistical Analysis Systems, 2000. SAS program Ver. 6. 12, SAS institute incorporation. Cary. NC 27513 USA.

Schaperclaus, W.; H. Kulow and K. Schreckenbach, (1992). Fish Disease. A.A. Balkema, Rotterdam, the Netherlands.

Soivio, A.; M. Niemisto, and M. Backstrom, , 1989. Fatty acid composition of Coregonusmuksun Pallas: changes during incubation, hatching, feeding and starvation. Aquaculture 79:163- 168.

Takeuchi, T.; J. Lu ; G.Yoshizaki and S.Satoh, 2002. Effect on the growth and body composition of juvenile tilapia Oreochromis niloticus fed raw Spirulina. Fisheries Science, 68: 34-40.

Tongsiri, K.; Mang-Amphan and P. Yuwadee, 2010. Effect of Replacing Fishmeal with Spirulina on Growth, Carcass Composition and pigment of the Mekong Giant Catfish. Asian Journal of Agricultural Sciences 2(3): 106-110.

Velasquez, S. and J. Ragaza, 2015. Dietary Spirulina (Spirulina platensis (Gomont) Geitler, K. (1925) replacement enhances performance of pond-and tank-reared juvenile Nile tilapia. (Oreochromis niloticus Linnaeus, 1758). Aquaculture Europe. Rotterdam, Netherlands Rotterdam, Netherlands. $4: 160$.

Watanbe,T.; W. Lio,; H. Takeuchi, and T. Yamamoto, 1990. Effect of dietary Spirulina supplement on growth performance and flesh lipids of cultured striped jack J. Tokyo Univ. Fish. 77: $231-239$.

Watanuki, H.; K. Ota,; A. C. Malin ; A. R. Tassakka; T. Kato, and M. Sakai , 2006. Immune stimulant effects of dietary Spirulina platensis on carp, Cyprinuscarpio. Aquaculture, 258: 157-163. 
Yue, Y.R. and Q.C. Zhou, 2008. Effect of replacing soybean meal with cottonseed meal on growth, feed utilization and hematological indexes for juvenile hybrid tilapia (Oreochromis niloticus $\times$ Oaureus). Aquaculture 284: 185-189.

Zeinab, A. K.; M.S. Aly ; A. Faiza and K. Fatma, 2015. Effect of Spirulina platensis and Lactobacillus rhamnosus on growth and biochemical performance of Nile Tilapia
(Oreochromis niloticus) fingerlings. Int. J. Curr. Microbiol. App. Sci 4(4): 747-763.

Zeinhom, M. M., 2004. Nutritional and physiological studies on fish. Ph. D. thesis. Faculty of Agriculture, Zagazig University. Egypt.

Zhu, M.; Deepak Srivastav; Deepak Umapathy and Shiva Kumar, 2011. Spirulina-The Nature's Wonder: A Review Sch. J. App. Med. Sci., 2011; 2(4C):1334-1339.

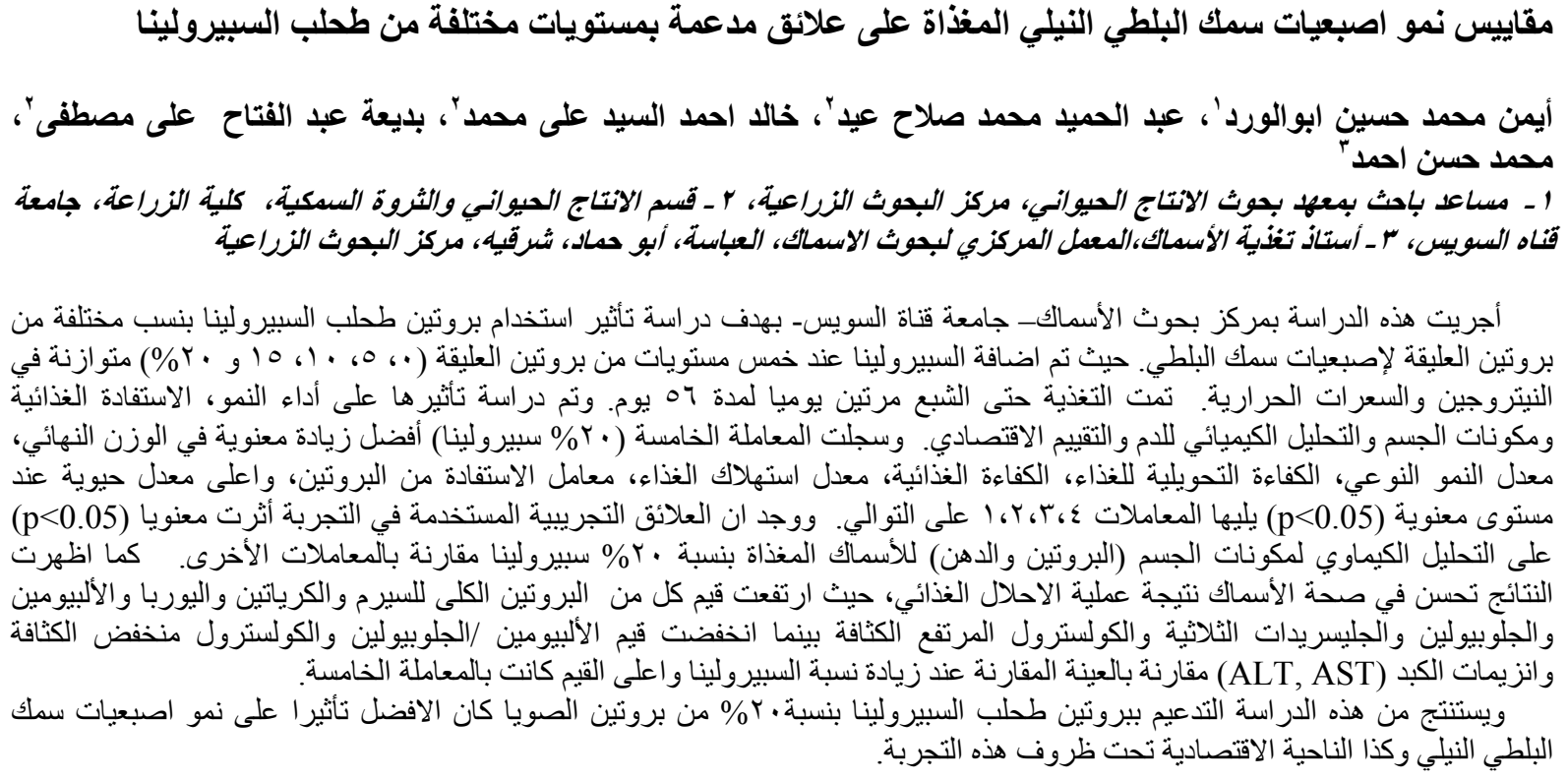

